\title{
Prestige, Prudence and Public Opinion in the 1882 British Occupation of Egypt
}

\author{
Dan Halvorson ${ }^{1}$ \\ Griffith Asia Institute \\ Griffith University
}

This article challenges both the "gentlemanly capitalist" thesis and "official mind" interpretation of the 1882 British occupation of Egypt. The former fails to adequately consider the political character of the Anglo-French financial Control overturned by the Urabist revolt in February 1882. The latter overstates the significance of the Suez Canal as both trigger and justification for military intervention. The article argues that the primary motivation behind the Egyptian occupation was the vindication of British prestige, vis-à-vis the Continental Powers, but especially in India and in the "East" by suppressing the threat to "civilised" order posed by the Urabist revolt. The protection of the Suez Canal and British financial and trade interests were secondary and derivative.

Dean Acheson has described prestige "as the shadow cast by power, which is of great deterrent importance”. ${ }^{2}$ The post-Napoleonic Pax Britannica cast a long shadow over the remainder of the long nineteenth century until 1914. By the 1880s, however, Britain's position in the international system was of a status quo Power in relative decline. $^{3}$ Thinly stretched over a large Empire, the maintenance of prestige was of critical importance for the protection of British imperial interests. The revival of intense strategic competition brought by Italian and German unification prompted the Conservative government of Benjamin Disraeli (1874-1880) in response to place great emphasis on the prestige of Britain’s Asiatic Empire. The ensuing political acrimony between “non-interventionist” Gladstonian Liberals and Tory "imperialists” was intended mainly for public and Party consumption, being more rhetorical than substantive. ${ }^{4}$ Despite their partisan stances, both Parties sought to maintain traditional

\footnotetext{
${ }^{1}$ Thanks to Jason Sharman, Michael Wesley, Joanne Wright and two peer reviewers for helpful comments on earlier drafts. Any errors remain the responsibility of the author. I also gratefully acknowledge scholarship funding from the Griffith Asia Institute.

${ }^{2}$ D. Acheson, Present at the Creation: My Years in the State Department (New York, 1969), p. 405.

${ }^{3}$ A. S. Thompson, Imperial Britain: The Empire in British Politics, c. 1880-1932 (London, 2000), pp. 23-24; P. Kennedy, The Realities Behind Diplomacy: Background Influences on British External Policy, 1865-1980 (London and Boston, 1981), pp. 69-70.

${ }^{4}$ See W. Baumgart, Imperialism: The Idea and Reality of British and French Colonial Expansion 1880-1914 (Oxford, 1982), pp. 48-49; P. J. Durrans, “A Two-Edged Sword: The Liberal Attack on
} 
British interests abroad through informal influence and neither wished to bring "more Oriental peoples into the Empire”. ${ }^{5}$

Large and influential sections of British Liberal opinion at the time also deprecated the value of India, and therefore of Egypt, as worth the risk of either a European war or a break with entente partner, France. ${ }^{6}$ The occupation of Egypt in 1882 directed by the second Liberal government of William Ewart Gladstone (188085) has consequently given rise to a vast literature spanning more than a century. Its bifurcation into economic and strategic schools of thought has been well documented. ${ }^{7}$ The scholarship of recent decades is dominated by two interpretations, both grounded in broader theories of British imperialism. P. J. Cain and A. G. Hopkins' "gentlemanly capitalist" thesis posits a metropolitan drive to imperial expansion emanating from the financial and service sectors of the City of London. ${ }^{8}$ The 1882 occupation was the result of a “conscious and sustained defence of Britain’s expanding economic interests in Egypt”. ${ }^{9}$ Ronald Robinson and John Gallagher's “official mind” thesis sees a status quo oriented Victorian metropole reacting to contingent peripheral disorder. The proto-nationalist revolt in Egypt (1879-82) led by Colonel Ahmed Urabi posed a strategic threat to the Suez Canal route to India. ${ }^{10}$

Drawing on an extensive reappraisal of the archival, parliamentary, newspaper and periodical sources on Anglo-Egyptian relations in the late-Victorian period, this article suggests that the dominant interpretations of the Egyptian occupation are only

Disraelian Imperialism”, The Journal of Imperial and Commonwealth History, Vol. 10, 3 (1982), pp. 275-278.

${ }^{5}$ R. Robinson and J. Gallagher, Africa and the Victorians (London and Basingstoke, 1961), p. 85.

${ }^{6}$ See, for example, W. E. Gladstone, Aggression on Egypt and Freedom in the East (London, 1877); R.

D. Osborn, “The Value of Egypt to Great Britain”, The Contemporary Review, Vol. 41 (January 1882), pp. 30-31.

${ }^{7}$ See survey in A. G. Hopkins, "The Victorians and Africa: A Reconsideration of the Occupation of Egypt, 1882”, The Journal of African History, Vol. 27, 2 (1986), pp. 364-370.

8 This is, of course, a very brief treatment of Cain and Hopkins' theory of economic imperialism; see P.

J. Cain and A. G. Hopkins, British Imperialism, 1688-2000, $2^{\text {nd }}$ ed. (London, 2002).

${ }^{9}$ Hopkins, "The Victorians and Africa", p. 13

${ }^{10}$ Robinson and Gallagher, Africa and the Victorians, pp. 94-121. 
partially sustainable. The following analysis focuses primarily on the acute phase of the Egyptian crisis from 9 September 1881 until Cairo was occupied on 15 September 1882. The evidence cited herein strongly implies that Egypt's international financial obligations, and the safety of the Canal, the threat to which was doubtful even at the time, could have been secured by making terms with Urabi. ${ }^{11}$ Indeed, by late June 1882, the Continental Powers were treating Urabi's nationalist regime as an accomplished fact. This course of action would have been consistent with the Gladstonian foreign policy principles laid out in the Midlothian election campaign of 1879, which, as counter to Disraeli-Toryism, stressed the equality of nations and respect for the will of "civilised” Europe. ${ }^{12}$ The adamant British refusals to treat with Urabi, in opposition to the other Powers and contrary to Liberal principles, suggest that other motives were at play at the height of the Egyptian crisis.

The article argues that the primary motive behind the Egyptian occupation was the vindication of British prestige, vis-à-vis the Continental Powers, but especially in India and the East, by suppressing the threat to "civilised" order posed by the Urabist revolt. The protection of the Suez Canal and British financial and trade interests were secondary and derivative. ${ }^{13}$ Hans Morgenthau has made the point that prestige is an integral element of the competition for power in international politics. However

\footnotetext{
${ }^{11}$ D. A. Farnie, East and West of Suez: The Suez Canal in History 1854-1956 (Oxford, 1969), pp. 291294.

${ }^{12}$ See W. E. Gladstone, Midlothian Speeches 1879 (Leicester, 1971), pp. 115-117, 123.

${ }^{13}$ The conceptual foundations for the argument developed here are suggested in R. Hyam, "The Primacy of Geopolitics: The Dynamics of British Imperial Policy, 1763-1963”, The Journal of Imperial and Commonwealth History, Vol. 27, 2 (1999), pp. 27-52. Other scholars such as David Steele and M. E. Yapp have previously noted the theme of prestige with respect to India in the Egyptian Crisis, although it has not been developed in the context of the events and decision-making examined in this article; see D. Steele, "Britain and Egypt 1882-1914: The Containment of Islamic Nationalism”, in K.M. Wilson, ed., Imperialism and Nationalism in the Middle East (London, 1983), pp. 1-3; and M.E. Yapp, The Making of the Modern Near East 1792-1923 (London, 1987), pp. 81-82, 227-228. Robert T. Harrison has also made the connection between public opinion and imperial prestige, and argued that the main purpose of the Egypt occupation was to safeguard India. This article also shares Harrison's view that the Liberal Cabinet's attitude toward the ineffectual Conference of the Powers (22 June - 14 August 1882) was disingenuous, but for different reasons than those claimed by Harrison. See R.T. Harrison, Gladstone's Imperialism in Egypt: Techniques of Domination (Westport, CT, 1995), pp. 3-4, 77, 97-102 and 113-115.
} 
prestige is rarely sought or maintained as an end in itself, but to serve a policy of imperialism or the status quo. The evaluation made by foreign observers of the power capabilities of a state is conditioned by the prestige it carries. And as suggested by the Acheson quote above, this can profoundly affect the calculations of revisionist actors in seeking to challenge the status quo. Britain's empire in India and the East was grounded on a reputation for unchallengeable power tempered by restraint. On this basis, a few thousand British officials were able to rule hundreds of millions of people until the defeat by Japan in World War II shattered British imperial prestige. ${ }^{14}$

In pursuit of its Egypt policy, Gladstone’s Liberal Cabinet was forced to seek a precarious balance between dual imperatives, which at the time resulted in accusations of vacillation and indecisiveness in the press and by the Opposition. The need to vindicate British prestige, reinforced by a vociferous public opinion, had to be accommodated with the acute prudential concern of placing the Egyptian Question before a Conference of the Powers. The three elements of the argument presented here: prestige, prudence and public opinion were initially in tension with one another, but ultimately were mutually reinforcing in the Cabinet's decision to occupy Egypt and in its timing. Imperial strategy required that the government maintain British prestige by putting down the revolt in Egypt while prudently avoiding conflict with the other Powers. Reinforcing these imperatives was the public opinion requirement that locations deemed essential to the prosperity and prestige of the Empire be seen to be orderly and safe. Or, in the words of Robinson and Gallagher, it was incumbent on British governments to "respect the public's thirst for peace, economy and prestige" in conducting imperial policy. ${ }^{15}$

\footnotetext{
${ }^{14}$ H. J. Morgenthau, Politics among Nations: the Struggle for Power and Peace, $5^{\text {th }}$ rev. ed. (New York, 1978), pp. 77-88.

${ }^{15}$ Robinson and Gallagher, Africa and the Victorians, p. 23.
} 
In a sustained critique of Africa and the Victorians in 1986, A.G. Hopkins makes the charge that Robinson and Gallagher privilege the "subjective motives” of Cabinet decision-makers at the expense of "objective historical causation”. ${ }^{16}$ There can be little doubt that the origins of British influence at Cairo were financial, to be found in the nineteenth-century expansion of European trade and investment, and profligate public sector borrowing in the semi-colonial Ottoman periphery. ${ }^{17}$ That British military intervention in 1882 is reducible to this cause, however, is not sustainable due to the presence of "objective" political factors. France held rival and longstanding interests in the country, and viewed Egypt as part of its North African sphere of influence. The Egyptian Question was also derivative of the broader “Eastern Question” of Ottoman decline and therefore remained a European issue subject to the scrutiny and interference of all the Powers. ${ }^{18}$

By 1876, the Egyptian Khedivate was bankrupt and had been placed under the financial supervision of Britain and France. The Anglo-French "Dual Control” over Egyptian finances which was further strengthened in 1879 after the deposition of the Khedive Isma'il in favour of his weaker son, Tawfiq (1879-1892), ${ }^{19}$ was based on an explicitly political, not economic rationale. It was grounded on the understanding that neither Power of the liberal entente would "tolerate the establishment in Egypt of political influence on the part of any other European Power in competition with that of England and France”. ${ }^{20}$ Prior to 1882, the Control had served the main British interest of preventing any Power from gaining predominance on the Nile and

\footnotetext{
${ }^{16}$ Hopkins, "The Victorians and Africa”, p. 385.

17 See R. Owen, The Middle East in the World Economy 1800-1914 (London and New York, 1981), pp. 122-152.

${ }^{18}$ See, for example, Mr. Wyndham (St. Petersburg) to Earl Granville, 28 September 1881, F[oreign] O[ffice] 407/18/87; Sir H. Elliot (Vienna) to Granville, 11 January 1882, FO 407/19/58.

${ }^{19}$ The "Khedive" was the title of the Ottoman viceroy of Egypt. The Khedivate was made hereditary within the Muhammad Ali dynasty in 1866.

${ }^{20}$ Salisbury to Malet, 19 September 1879, Parliamentary Papers, Egypt, 14 (1884).
} 
threatening the Canal route to India. In practical terms, this meant ensuring sound financial governance at Cairo so that Egypt's international obligations under the Law of Liquidation (1880) would be met, thereby preventing any interference from the Powers. ${ }^{21}$ Britain's grand strategy in the Near East, however, of safeguarding routes to India by keeping Russia out of the Eastern Mediterranean and Asia Minor, remained centred on maintaining the integrity of the Ottoman Empire. Any change to the status quo in Egypt would therefore reopen the Eastern Question at the risk of Great Power conflict. Cain and Hopkins pay no attention to the wider strategic context to the Egyptian Question, while Robinson and Gallagher's analysis of the Cabinet's motives for intervention concentrate almost exclusively on Anglo-French relations.

Robinson and Gallagher's “official mind” interpretation also overstates the significance of the Suez Canal at the height of the Egyptian crisis when the evidence implies that its explanatory value was diminishing relative to the motives emphasised here. Indeed, as D.A. Farnie has noted, the Canal rates very few mentions in the contemporary sources in the months leading up to the intervention relative to the significance assigned to it by Robinson and Gallagher. And while the Suez Canal was no doubt an important imperial interest, it was not traversable at the time by the Admiralty’s larger warships. The Cape route to India continued to be given strategic priority in the 1880 s. $^{22}$

\section{The crisis unfolds and the Powers declare their interest}

This section describes the onset of the Egyptian crisis and demonstrates the profound challenge it posed to British prestige, vis-à-vis both the European Powers and for the Empire in the East. On 9 September 1881, Colonel Urabi’s military faction forced the dismissal of the Khedive's Council of Ministers, and convened the Chamber of

\footnotetext{
${ }^{21}$ The Law of Liquidation (1880) was negotiated between nine European creditor states, and could only be altered by their consent.

${ }^{22}$ Farnie, East and West of Suez, p. 292.
} 
Notables in support of a demand for constitutional government. ${ }^{23}$ British ControllerGeneral, Sir Auckland Colvin, was astonished by the Arab mutineers' flagrant disregard for the will of Europe: “They spoke like men convinced that they would be allowed to settle their own disputes with the Government; that Europe had neither the right nor the wish to interfere". ${ }^{24}$ To The Times correspondent at Cairo, Sir John Scott, the capitulation of 9 September was not that of the Khedive, but the surrender of Britain and France. It could not be disguised that the Urabist revolt had no "other object than the destruction of European interference with Egyptian administration”, 25

The hundreds of Europeans staffing the Egyptian Civil Service, international financial administrations and law courts were a major source of nationalist and Islamic resentment. The pan-Islamic thrust of the Arabic press became pointed from September 1881 with European administrators attacked as agents of Muslim oppression. ${ }^{26}$ The Times correspondent at Alexandria, C.F. Moberley Bell, reported that Islamic and nationalist sentiment had merged in the Urabist revolt. ${ }^{27}$ The movement represented Egypt against Europe, Muslim against Christian. Empowering the Chamber of Notables to exercise discretion over the Budget would overturn the Anglo-French Control, thereby posing a severe challenge to British prestige. ${ }^{28}$

The political chaos in Egypt served immediately to exacerbate Anglo-French rivalry. Gladstone was of the opinion that, if armed intervention in Egypt became

\footnotetext{
${ }^{23}$ Mr. Cookson (Cairo) to Granville, 9 September 1881, FO 407/18/1; FO 407/18/3; 14 September 1881, FO 407/18/58. The Chamber of Notables was a deliberative Assembly established in 1866. ${ }^{24}$ Memorandum by Mr. Colvin, 10 September 1881, in Cookson to Granville, 12 September 1881, FO 407/18/50.

${ }^{25}$ The Times, 27 September 1881, p. 8. British correspondents in Egypt were far from disinterested and impartial observers. Sir John Scott, for instance, was also a judge in the "Mixed Tribunals” established in 1875 to hear cases involving European residents in Egypt; see M.E. Chamberlain, "British Public Opinion and the Invasion of Egypt, 1882”, Trivium, Vol. 16 (1981), pp. 14-15.

${ }^{26}$ See, for example, Malet to Granville, 25 September 1881, FO 407/18/85; "Précis of Seven Articles from the Newspaper 'El Hejaz' of Sept. 26, 1881”, in Malet to Granville, 6 October 1881, FO 407/18/195.

${ }^{27}$ Moberley Bell, later a Managing Director of The Times, was a prominent figure in the English business community in Alexandria; see Chamberlain, "British Public Opinion and the Invasion of Egypt, 1882”, p. 15.

${ }^{28}$ The Times, 6 October 1881, p. 4.
} 
necessary, this was the responsibility of the Turkish Sultan as Suzerain. ${ }^{29}$ This was consistent with the British interest of keeping the other Powers out of Egypt, but irreconcilable with its core European interest of maintaining the liberal alliance with France to prevent German hegemony on the Continent. ${ }^{30}$ The French, however, were resolutely against any deployment of Turkish troops to Egypt. French Foreign Minister, Jules Barthélemey-Saint-Hilaire, "felt that such a step would be giving to the Sultan a greater hold upon that country; and he feared that the troops, if once landed, would be likely to remain there permanently". ${ }^{31}$ Such an "intervention would raise the pretensions of the Sultan, and increase his prestige through most of the Mahommedan population in North Africa; it would raise a spirit of fanaticism among these people in Tripoli and elsewhere”. ${ }^{32}$ France was extremely sensitive to panIslamic influences in North Africa, and it was for this reason that Turkish intervention was vehemently opposed.

British Governments were also wary of pan-Islamic sentiment, although for different reasons. The most dangerous threat to British imperial authority in the nineteenth century had been the Indian Mutiny of 1857-59. The origins of the Mutiny were complex, but involved a civil-military uprising in North-Central India focused on the Muslim Dynasty of the Mogul King of Delhi, which was once the dominant force on the subcontinent. Since then, the British had viewed "fanatical" Islamic movements as the most acute risk to European influence and control in the Orient. ${ }^{33}$ The pan-Islamic subtext to the Egyptian revolt and possible Turkish intervention played on these existing fears, which were well founded according to an 1880 Cabinet

\footnotetext{
${ }^{29}$ Mr. Gladstone to Granville (private), 13 September 1881, Granville Papers, P[ublic] R[ecords] O[ffice] (now The National Archives, Kew, U.K.) 30/29/124.

${ }^{30}$ C. J. Lowe, The Reluctant Imperialists: British Foreign Policy 1878-1902 (New York, 1969), p. 40.

${ }^{31}$ Mr. Adams (Paris) to Granville, 11 September 1881, FO 407/18/10.

32 Adams to Granville, 13 September 1881, FO 407/18/22.

33 Steele, “Britain and Egypt 1882-1914”, p. 2.
} 
summary entitled, “Attitude of the Mussulmans in India, throughout Asia, and in Egypt”. In March 1879, for example, the High Sheriff of Mecca communicated to then Foreign Secretary, Lord Salisbury, that the

state of Mussulman feeling in India, throughout Asia, and in Egypt, is such that a slight event might create wars and raise revolt in all Mahommedan countries. Suspicion, mistrust, doubt, and irritation have taken deep root in the hearts of Mussulmans, and these sentiments ... can only gradually be eradicated and confidence restored by the exercise of great prudence and delicacy, and by avoiding any and every measure which may excite fanaticism. ${ }^{34}$

In addition to the risk of inflaming Muslim sentiment in India, the political crisis in Egypt prompted the other Powers to declare their interest. An editorial in The Times on 23 September 1881 claimed that the rebellion in Egypt was therefore a direct threat to British routes and communications to the Indian Empire, because "all or any of the powers of Europe who up to this time have left the country to the management of England and France might interfere”. ${ }^{35}$ On 17 September, for instance, Foreign Secretary Lord Granville rebuffed a proposal "to admit Italian intervention in Egyptian affairs on the same footing as England and France”. ${ }^{36}$ The German press was claiming that Egyptian proceedings were of the greatest importance for all Europe. ${ }^{37}$ And British Ambassador at Constantinople, Lord Dufferin, confirmed on 28 September that Germany and Russia were indeed insisting

\footnotetext{
${ }^{34}$ Mr Zohrab (British Consul at Jeddah) to Salisbury, 12 March 1879, CAB 31/1/8

${ }^{35}$ The Times, 23 September 1881, p. 8.

${ }^{36}$ Granville to Mr. MacDonell (Rome), 18 September 1881, FO 407/18/44.

${ }^{37}$ Quoted in The Times, 20 September 1881, p. 3.
} 
“on a right of interference in Egyptian affairs”. ${ }^{38}$ Such approaches by other European governments constituted a direct challenge to British and French prestige as the “controlling” Powers in Egypt.

It was also clearly recognised at the British Foreign Office by the end of September 1881 that any Turkish intervention to quell the revolt in Egypt would reopen the Eastern Question:

If the Porte were to intervene in any manner in Egypt, the question would thereby become a European one. The Great powers who were guarantors, either as parties to the Treaty of 1840 or to that of Berlin, would not fail to claim their proper share in the settlement of the matter. France and England would of necessity lose the exclusive patronage of Egypt which they enjoyed at this moment; Egyptian questions would be subject to the decision of seven Powers instead of two, and it was impossible to say what might be the result. ${ }^{39}$

This indeed appeared to be Bismarck’s intention. British Ambassador to Germany, Lord Ampthill, was "informed that Prince Bismarck is not unfavourable to a Turkish occupation of Egypt", 40 and that this "opinion is likely to be shared both by Russia and by Austria”. 41

\footnotetext{
${ }^{38}$ The Earl of Dufferin (Constantinople) to Granville, 28 September 1881, FO 407/18/69.

${ }^{39}$ Granville to Lord Lyons (Paris), 30 September 1881, FO 407/18/72. The "Sublime Porte" referred to the court of the Sultan. The term "Porte" was also used to denote the Ottoman Foreign Ministry. The 1840 Treaty of London between Britain, Austria, Prussia, Russia and the Ottoman Empire recognised the hereditary rule in Egypt of Muhammad Ali and his heirs, while also confirming Egypt as integral to the Ottoman Empire. By the 1878 Treaty of Berlin between all European Powers and Constantinople, the Ottoman Empire ceded Cyprus to Britain, Bosnia-Herzegovina to Austria, and various territories in Asia Minor to Russia. The 1878 Treaty also partitioned the Ottoman province of Bulgaria into three parts: an independent Bulgaria north of the Balkan Mountains, the semi-autonomous Eastern Rumelia in the centre, with the southern portion remaining as an Ottoman dependency.

${ }^{40}$ Lord Ampthill (Berlin) to Granville, 3 October 1881, FO 407/18/89.

${ }^{41}$ Ampthill to Granville, 3 October 1881, FO 407/18/141.
} 
In response, British and French representatives delivered a joint note to the Egyptian government on 8 January 1882 guaranteeing the Khedival autocracy and therefore the status quo in Egypt. The note declared that the maintenance of the Khedive's regime was alone able to guarantee civilised order in Egypt in which Britain and France were equally interested. ${ }^{42}$ With the May 1881 French invasion of Tunis as a precedent, the note achieved the reverse of its intended effect, serving only to unify the disparate military and constitutionalist elements of the Egyptian national movement in common opposition to Britain and France. ${ }^{43}$

Colvin reported on 11 January 1882 that the Chamber of Notables, supported by Urabi and the army, was insisting on its right to vote the budget. ${ }^{44}$ Granville wrote to Gladstone on 15 January that the position of the Chamber was “contrary to Treaty engagements" and "cannot be agreed to". ${ }^{45}$ British Agent and Consul-General at Cairo, Edward Malet, warned on 20 January that the Chamber's intention formed only part “of a complete scheme of revolution". ${ }^{46}$ Three days later Colvin concluded that the "state of things admits no local remedy" ${ }^{47}$ Gladstone confirmed on 31 January that, as to the Control "and internationally sanctioned laws we withhold it bodily from the Notables”. ${ }^{48}$ Having explicitly guaranteed the Khedival regime and the political status quo in Egypt on 8 January, the refusal of the rebel government to reinstate the Control was an unacceptable affront to British prestige.

It is clear from the above that British representatives in Egypt felt that some form of external intervention was necessary by the end of January 1882. However, it

\footnotetext{
42 "Despatch from H.M. Agent and Consul-General at Cairo forwarding a Copy of the Note presented to the Khedive by the English and French Agents”, Parliamentary Papers, Egypt, 2 (1882).

${ }^{43}$ Malet to Granville, 10 January 1882, FO 407/19/75.

${ }^{44}$ Memorandum by Colvin, inclosure in Malet to Granville, 11 January 1882, FO 407/19/78.

${ }^{45}$ Granville to Gladstone (private), 15 January 1882, PRO 30/29/125. The treaty engagements referred to here were the provisions of the abovementioned Law of Liquidation (1880).

${ }^{46}$ Malet to Granville, 20 January 1882, FO 407/19/87.

${ }^{47}$ Memorandum by Colvin, in Malet to Granville, 23 January 1882, FO 407/19/127.

${ }^{48}$ Gladstone to Granville (private), 31 January 1882, PRO 30/29/125.
} 
was not until 11 May that the Cabinet shared this position, despite a number of serious provocations on the ground in Egypt over the intervening months. The formation of a new Nationalist Council of Ministers on 5 February, responsible, in effect, to the Chamber rather than the Khedive, with Urabi as War Minister, coincided also with reports that the Egyptian military had begun to upgrade its coastal fortifications. A new Organic Law allowing the Chamber to sanction the budget was also passed and the Anglo-French Controllers excluded from the Council. ${ }^{49}$ The delay suggests that factors other than prestige were also exerting an influence on Cabinet decisionmaking at the height of the Egyptian crisis.

\section{The press, public opinion and prudence}

This section outlines the symbiotic relationship between policy elites in London, British officials abroad, the reporting of foreign corespondents, and perceptions of public opinion in the late-Victorian era. It then demonstrates that, rather than vacillation and indecisiveness, the delay in Cabinet decision-making in the first half of 1882 was primarily a function of the tension between the prudence required by the exigencies of European power politics, and on the other hand, the escalating pressures for armed intervention expressed by a vociferous press and public opinion.

British press and public opinion began to pay greater attention to the Egyptian Crisis in early 1882. The period from 1865 to 1885 marked a shift in the interplay between British foreign policy and domestic politics. The traditional sources of power and decision, the Crown, Cabinet, Foreign Office, Parliament and political parties had to respond to the growing pressures of public opinion, felt in an enlarged franchise and expanded party memberships, increased literacy rates, and a burgeoning popular

\footnotetext{
${ }^{49}$ See Malet to Granville, 1, 4 and 5 February 1882, FO 407/19/139, 162, 166; Memorandum by Colvin, 11 February 1882, in Malet to Granville, 13 February 1882, FO 407/19/273.
} 
press. ${ }^{50}$ The importance of mobilising public opinion against political rivals was first recognised and manipulated in a concerted fashion by Disraeli and Gladstone in the 1870s. Large amounts of daily press coverage were allocated to political reporting and parliamentary debates were published in full. The influence of newspapers and editors in the political process was thus very significant, as this was the predominant means of communication between political elites and the mass of the population. ${ }^{51}$

Prior to the advent of opinion polling, the temper of public sentiment was, however, difficult to gauge. In the late-Victorian era, perceptions of public opinion were mediated into the Cabinet decision-making process through the views of parliamentarians, but more importantly, by the tone and disposition of the masscirculation press, which, however inaccurately, was considered synonymous with public opinion. ${ }^{52}$ No suggestion is made here that British governments were led by public opinion. Rather, perceptions of public opinion tended to function as a negative constraint on policymakers, precluding government inaction on highly publicised issues. $^{53}$ In foreign affairs reporting, correspondents worked very closely with British representatives abroad, and in some cases were one and the same. For example, Auckland Colvin, the British Controller of finances at Cairo, was also the Egypt correspondent for the liberal Pall Mall Gazette, which was Gladstone’s preferred daily paper. $^{54}$ The material reported by foreign correspondents was therefore not disinterested and tended to reflect the views of British officials and the expatriate community.

\footnotetext{
${ }^{50}$ Thompson, Imperial Britain, p. 52; Marvin Swartz, The Politics of Foreign Policy in the Era of Disraeli and Gladstone (New York, 1985), p. 1.

${ }^{51}$ Kennedy, The Realities Behind Diplomacy, p. 52; Thompson, Imperial Britain, p. 62.

${ }^{52}$ Kennedy, The Realities Behind Diplomacy, p. 51.

${ }^{53}$ Lowe, The Reluctant Imperialists, p. 12.

${ }^{54}$ See M. E. Chamberlain (1981), 'British Public Opinion and the Invasion of Egypt, 1882', Trivium, 16, pp. 14-16; see A.G. Hopkins (1986), 'The Victorians and Africa: A Reconsideration of the Occupation of Egypt, 1882', The Journal of African History, 27 (2), p. 383.
} 
The most important factor in the policy drift in the early months of 1882 was that, as the political situation at Cairo deteriorated; the ominous rumblings from the Continent grew louder, raising unavoidable prudential concerns. According to Morgenthau, political realism holds that a rational foreign policy "complies both with the moral precept of prudence and the political requirement of success”. From a realist perspective, prudence, or "the weighing of the consequences of alternative political actions", is the "supreme virtue in politics". ${ }^{55}$ The evidence cited below demonstrates that a realist ethic of prudence guided the actions of British decision-makers from early 1882 until the Conference of the Powers was seen to have run its course in late July. All British actions towards Egypt had to be weighed against the overriding risk of Great Power conflict. The need for prudence, however, was immediately in tension with conservative opinion, which demanded a "forward policy". After some initial non-interventionist caution, the liberal press also began to push for military action as the political crisis in Egypt degenerated into civil disorder.

A front-page article in the Pall Mall Gazette on 2 February 1882 clearly shows why the Cabinet was reluctant to commit to armed action. It stated that the Egyptian Question was "fraught with the gravest issues as to European peace". The perils attending armed intervention "are so formidable, and the jealousy of the Powers so great, that there can be no desire on the part of any Ministry to commit itself to precipitate action". ${ }^{56}$ Russia continued to assert that Egypt was part of the Eastern Question and that a European Concert must precede any settlement. The Journal de St. Pêtersbourg, the "semi-official organ" of the Imperial Court delivered the blunt warning that

\footnotetext{
${ }^{55}$ Morgenthau, Politics among Nations, pp. 8, 11.

${ }^{56}$ The Pall Mall Gazette, 2 February 1882, p. 1.
} 
the maintenance of peace is the most urgent want of all nations, but this aspiration is not strong enough to secure the acceptance of solutions which one power or another might seek to bring about by their own initiative, and it would not be prudent to subject it to so trying a test. ${ }^{57}$

In early February, Russia, Italy, Austria and Germany made a joint communication to Constantinople that the status quo in Egypt "could not be modified except by an accord between the Great Powers and the Suzerain Power". ${ }^{58}$ It is clear from this unanimity that a prudent policy would require that the British Cabinet place the Egyptian question under the customary jurisdiction of a European Concert, carrying with it constraints on British action. Bismarck accepted the British proposal for a Conference as "conducive to the maintenance of the peaceful dispositions at present prevailing among the Powers”. ${ }^{5}$

The government's referral of the Egyptian Question to Europe prompted the conservative Standard to accuse the Cabinet of pursuing a policy of vacillation and inactivity out of fear to offend anyone, thereby surrendering “'Britain’s special interests in Egypt'”. ${ }^{60}$ Questions were also raised as to what guarantees for the security of the Suez Canal could be expected from the Egyptian National movement, especially in the event of "a Mahommedan rising in India”. ${ }^{61}$ The lack of public order and security for Europeans in Egypt due to the "appearance of armed bands of lawless men", and "the increase in the temper of the Moslem mob" also became prominent elements of the press coverage from February 1882 onwards. ${ }^{62}$ The public nerve that

\footnotetext{
${ }^{57}$ Quoted in The Daily News, 28 January 1882, p. 5.

${ }^{58}$ Dufferin to Granville, 2 February 1882, FO 407/19/149.

${ }^{59}$ Ampthill to Granville, 15 February 1882, FO 407/19/249.

${ }^{60}$ Quoted in The Pall Mall Gazette, 24 February 1882, p. 12.

${ }^{61}$ The Pall Mall Gazette, 25 February 1882, p. 2.

${ }^{62}$ Ibid., 13 March 1882, p. 1.
} 
required order be seen to be kept in locations essential to the security and prosperity of Empire had clearly been touched. The escalating levels of hysteria in the daily press created a backdrop of urgency to Cabinet decision-making that could not be ignored. The build-up of excitement and outrage in the popular press signalled by an ultimatum to Urabi’s Ministry to submit on 25 May, and its summary rejection, was, however, deflated by the formal announcement on 1 June of the Conference of the Powers at Constantinople.

\section{The policy of intervention}

This section traces the hardening of attitudes toward the Urabist revolt by leading figures in the British Cabinet between late-February 1882 and the Alexandria massacre of June 11. Exercising prudence with respect to the Powers had to be balanced with the need for increasingly assertive measures to respond to Urabi's challenge to British prestige. It is shown below that rather than vacillation and indecisiveness on the part of key decision-makers, contingency plans for a military intervention were in place by late-May, and secret preparations in both England and India for an expeditionary force were quickly instigated after the June 11 riots in Alexandria had marked the outbreak of violent civil disorder.

The Anglo-French Control in Egypt was representative of the prestige carried by Britain and France, and more generally, of Europe, in the Muslim world. It also represented the "superiority of the interests and the rights of France and England over those of any other Power". ${ }^{63}$ Though Urabi’s de facto National government did not breach Egypt's international financial obligations, and indeed, made repeated declarations that it would not do so, ${ }^{64}$ it had repudiated the Control. And as noted above, the Anglo-French Control was explicitly political, rather than economic in

\footnotetext{
${ }^{63}$ Lyons to Granville, 21 February 1882, FO 407/19/292.

${ }^{64}$ See, for example, "Programme of the National Party of Egypt", The Times, 3 January 1882, p. 4.
} 
nature. Malet reported from Cairo on 17 February 1882 his growing impression that the overturning of the Control was symbolic of wider "revolutionary feeling, of which anti-Europeanism is the real base”. ${ }^{65}$ This consideration became increasingly salient. As greater pressure was applied to regain political control in Egypt, the "financial" disorder developed into physical disorder threatening European lives and property, which further inflamed press and public opinion in Britain.

Matters came to a head when a conspiracy to kill Urabi was uncovered on 20 April 1882 and the Khedive refused to court martial a high-ranking officer without reference to Constantinople. The Nationalist Ministry accused the Khedive of diminishing Egypt's autonomy and on 10 May convoked the Chamber of Notables on its own authority. ${ }^{66}$ According to British representatives, the purpose of this was to coerce the approval of the Chamber to dethrone the Khedive for a military dictatorship led by Urabi. ${ }^{67}$ The situation, from London's perspective, was now of a genuinely revolutionary character. From this point forward the British Cabinet was resolved that some form of armed intervention was necessary for the restoration of order in Egypt.

In formulating a policy of intervention, the Cabinet was confronted with three conflicting imperatives. The first was the prudential concern that any change to the status quo in Egypt, and therefore to the "Eastern Question", be placed under the jurisdiction of a European Concert. The second was that of maintaining, as far as possible, the liberal entente with France. The third was that, as the crisis continued to escalate, the perception of damage to British prestige vis-à-vis the Continental Powers, but particularly in India and the East, became of paramount concern.

\footnotetext{
${ }^{65}$ Malet to Granville, 17 February 1882, FO 407/19/259.

${ }^{66}$ Ibid., 10 May 1882, FO 407/20/159.

${ }^{67}$ Ibid., 11 May 1882, FO 407/20/173.
} 
The first act was the despatch of British and French warships to Alexandria on 15 May 1882. From the British perspective, a successful naval demonstration in overawing Urabi would render a Conference of the Powers and Turkish intervention superfluous, thereby preventing a break with France. In conjunction with the arrival of the squadrons, the British and French Agents were to urge the Khedive to dismiss Urabi’s Ministry. ${ }^{68}$ A note was presented to Urabi on 25 May demanding his exile and the resignation of the present Council of Ministers. ${ }^{69}$ This was immediately rejected with the assertion that the Powers had no right to interfere in Egypt. The army and police in Alexandria refused to guarantee order unless Urabi and his Ministers were officially reinstated by the Khedive. This duly occurred on 28 May after intense pressure from Christian and Jewish leaders fearing communal violence in the event of a refusal. ${ }^{70}$ The Anglo-French view on the ground was that this was a disastrous development. The Khedive was now completely marginalised. ${ }^{71}$ These events constituted a further sharp blow to British prestige.

The British Cabinet then decided that the Sultan, as legitimate Suzerain, be invited to intervene under strict Anglo-French supervision. The preference for Turkish military action was complicated by Germany's objection to any exclusive AngloFrench supervision, while French public opinion had turned virulently against the Freycinet Ministry at the mere rumour of its assent to Turkish intervention. ${ }^{72}$ An acceptance by Cabinet that a break with France over the question of Turkish intervention might not be avoided was evident by the end of May 1882 .

The archival evidence clearly indicates that British military contingencies were also being considered in secrecy by this time. For example, Granville wrote to

\footnotetext{
${ }^{68}$ Granville to Malet, 15 May 1882, FO 407/20/344.

${ }^{69}$ Malet to Granville, 25 May 1882, FO 407/20/537.

${ }^{70}$ See reports in The Standard, 29 May 1882, p. 5; 30 May 1882, p. 5

${ }^{71}$ Malet to Granville, 28 May 1882, FO 407/20/624.

${ }^{72}$ The Morning Post, 27 May 1882, p. 5; Lyons to Granville, 29 May 1882, FO 407/20/633.
} 
War Secretary, Hugh Childers, on 29 May, "things do not look pleasant at Paris or Cairo - I trust that we shall not have to break with the French, but there is a possibility of it. I believe I rightly understood that you had privately considered at the War Office, all contingencies”. ${ }^{73}$ Actual military preparations for an expeditionary force were initiated in Britain on 16 June 1882. Preparations also appear to have been made for troops from India prior to this according to correspondence between Granville and Northbrook, First Lord of the Admiralty, on 13 June. ${ }^{74}$ This suggests that, at least among some prominent members of Cabinet, the prospect of Turkish intervention was considered unlikely prior to the first sitting of the Conference on June 17 . The evidence that military preparations were already in progress at this time supports the proposition that, from the British perspective, the proposed Conference was intended to serve prudential purposes rather than achieve any effective outcome.

A Conference of the Powers and the Porte, to sit at Constantinople, was publicly announced on 1 June 1882. Concerns were immediately raised in the British press as to the diminution of national prestige, especially in relation to Germany. The Daily Telegraph complained that any international settlement would remove forever "England's preponderating influence on the banks of the Nile," while "everyday the tone of the two German Powers is getting firmer and more peremptory”. ${ }^{75}$ The French objective for the Conference was to seek a mandate for an Anglo-French military intervention to avert any Turkish interference. ${ }^{76}$ This was in direct conflict with Gladstone's expectations. The Prime Minister advised Queen Victoria on 31 May of the likelihood "the Conference will promote a settlement through regulated Turkish

\footnotetext{
${ }^{73}$ Granville to Mr. H. Childers (private), 29 May 1882, PRO 30/29/118.

${ }^{74}$ See exchange of letters between Childers and the Duke of Cambridge, Commander-in-Chief British Army, recorded in Spencer Childers, The Life and Correspondence of the Right Hon. Hugh C.E. Childers 1827-1896, Vol. II (London, 1901), pp. 88-89; and Northbrook to Granville (private), 13 June 1882, PRO 30/29/138.

${ }^{75}$ The Daily Telegraph, 2 June 1882, p. 5.

${ }^{76}$ Ibid., 31 May 1882, p. 5.
} 
intervention". ${ }^{77}$ The Anglo-French imperative for the Conference to meet was heightened by serious rioting in Alexandria on 11 June, in which fifty Europeans were killed under the guns of the squadrons, including a British naval engineer reportedly murdered as Egyptian police looked on. ${ }^{78}$

\section{Prestige, public opinion and the Conference}

This section shows that after the Alexandria massacre, the damage to British prestige emerged as the dominant theme in Egypt policy debate, both in the press and in Cabinet. It was felt that if British lives, interests and property could be attacked with impunity in Egypt; this placed them at great risk in India and throughout the East more generally. The Conference, yet to sit because of Turkish intransigence, was regarded in the press as futile as were the prospects of any decisive French action. ${ }^{79}$ According to Under Secretary for Foreign Affairs, Sir Charles Dilke and India Secretary, Lord Hartington, public sentiment and the majority of Liberal Party opinion was now demanding some form of armed British intervention in Egypt. ${ }^{80}$ The humiliation of having to beg Urabi to protect British lives and property after the ultimatum demanding his exile was an intolerable affront to imperial prestige. ${ }^{81}$

Granville pressed for the Conference to meet on 13 June, making the express request that the Sultan be invited to intervene militarily. The object of the proposed

\footnotetext{
${ }^{77}$ Gladstone to Queen Victoria, 31 May 1882, CAB 41/16/27.

${ }^{78}$ Vice-Consul Calvert (Alexandria) to Granville, 11 June 1882, FO 407/20/885. A number of studies using Egyptian archival material have subsequently cast doubt on the seriousness of the Alexandria riots and Urabi's involvement. In their despatches to London, Britain’s “men on the spot” may have exaggerated the disorder to encourage a forward policy; see J. S. Galbraith and A. L. Al-SayyidMarsot, “The British Occupation of Egypt: Another View”, International Journal of Middle Eastern Studies, Vol. 9, 4 (1978), p. 483; J. R. I. Cole, "Of Crowds and Empires: Afro-Asian Riots and European Expansion, 1857-1882”, Comparative Studies in Society and History, Vol. 31, 1 (1989), pp. 121-128. For the "men on the spot” interpretation, see A. Schölch (1976), "The 'Men on the Spot' and the English Occupation of Egypt in 1882”, The Historical Journal, Vol. 19, 3 (1976), pp. 773-785. ${ }^{79}$ See The Daily Telegraph, 13 June 1882, p. 5; 14 June 1882, p. 5; The Pall Mall Gazette, 14 June 1882, p. 11.

${ }^{80}$ The Marquis of Hartington to Granville (private), 16 June 1882, PRO 30/29/132; Dilke quoted in S. Gwynn and G. M. Tuckwell, The Life of the Rt. Hon. Sir Charles W. Dilke, Vol. I (London, 1917), p. 460.

${ }^{81}$ The Standard, 15 June 1882, p. 5.
} 
intervention, which would be strictly limited to one month only, was the restoration of the status quo ante Urabi. ${ }^{82}$ That this impossibly stringent time frame was imposed casts significant doubt on the seriousness of this proposal. This is especially so when viewed in conjunction with the evidence that Northbrook was concurrently "making preparations for the naval force required to hold the Canal”, while Hartington was making preparations with Lord Ripon, Viceroy of India, "to have a Brigade ready to send to Suez". ${ }^{83}$ It would seem that the British pressure for Turkish intervention was disingenuous, serving the prudential function of being seen to consult, while in the background military preparations were carried on.

In the weeks following the Alexandria massacre, the question of prestige acquired an urgency that increased in parallel with the delay and ineffectiveness of the Conference. Granville’s invitation for regulated Turkish intervention was refused by Germany on 16 June 1882 because the French had yet to acquiesce and the conditions were so severe that Bismarck was unwilling to pressure the Sultan to accept them. ${ }^{84}$ Reports also suggested that the French Prime Minister, Charles de Freycinet, could not countenance Turkish intervention or his precarious government would fall. ${ }^{85}$ On the same day, telegrams from Cairo reported that, under pressure from the German and Austrian Consuls, the Khedive was treating with Urabi by forming an agreeable Ministry, ${ }^{86}$ thus disregarding the Anglo-French ultimatum of 25 May and gaining impunity for the Alexandria massacre of 11 June. Dufferin reported on 17 June that the first "meeting of the Ambassadors on the affairs of Egypt took place to-day. None of them had instructions”. ${ }^{87}$ From around 17 June then, it would seem that little

\footnotetext{
${ }^{82}$ Granville to Ampthill, 13 June 1882, FO 407/20/955.

${ }^{83}$ Northbrook to Granville (private), 13 June 1882, PRO 30/29/138.

${ }^{84}$ Ampthill to Granville, 16 June 1882, FO 407/20/1096.

${ }^{85}$ Ibid., 16 June 1882, F.O. 407/20/1212.

${ }^{86}$ Malet to Granville, 16 June 1882, FO 407/20/1121.

${ }^{87}$ Dufferin to Granville, 17 June 1882, FO 407/20/1171.
} 
expectation could have been held by Cabinet that the Conference would produce any effective outcome that did not involve British armed intervention.

India Secretary Hartington clearly recognised the further unacceptable blow to British prestige that these events represented. He wrote to Granville on 18 June 1882 that it might have been possible for the other Powers to accept a compromise with Urabi, but that the defence of British "honour" and "interests" meant "it is not possible for us”. ${ }^{88}$ Dufferin was issued new instructions to take to the Conference on 21 June. The Ministry in Egypt could not be accepted. If the Sultan was unwilling to send troops, the Powers were to be asked "to provide or sanction a military intervention, other than Turkish, under their authority”. ${ }^{89}$ On the same day, the Cabinet resolved in secrecy to make preparations for the protection of the Suez Canal without reference to the Conference. ${ }^{90}$ The Commander of the British naval squadron, Admiral Seymour, telegraphed on 22 June that all British subjects who wished to leave Egypt had been embarked, thereby removing "the principal cause of anxiety in calculating what action should be taken”. ${ }^{91}$

While secret contingency planning had been taking place at the War Office since at least the end of May, reports in the press on 24 June from sources "close to government", that a "large force" was being put in readiness "for immediate deployment in Egypt”, suggests that pressure from public opinion was starting to bite. $^{92}$ That serious military preparation was taking place concurrently with the Conference, which was almost universally seen to be ineffectual, supports the proposition that the Cabinet's intent in pursuing it by this time was prudential. The

\footnotetext{
${ }^{88}$ See Hartington to Granville (private), 18 June 1882, PRO 30/29/132.

${ }^{89}$ Granville to Dufferin, 21 June 1882, FO 407/20/1339.

${ }^{90}$ Gladstone, Cabinet minutes, 21 June 1882, H. C. G. Matthew, ed., The Gladstone Diaries, Vol. X (Oxford, 1990), p. 284.

${ }^{91}$ Secretary to the Admiralty to Lord Tenterden (Foreign Office), 22 June 1882, FO 407/20/1350.

${ }^{92}$ The Pall Mall Gazette, 24 June 1882, p. 8.
} 
delay inherent in the Conference, and the perception of vacillation that it projected onto the government had to be balanced against managing the overriding risk of Great Power conflict. It was a reasonable calculation that, when the Conference had been seen to run its course, if the Cabinet vindicated "effectually, and by arms if needful, the interests of England on the Nile and the Canal, the country will be ready to condone their blunders, their vacillation, and their delay”, ${ }^{93}$

On 28 June, The Times reported that Britain was the only Power not treating the Urabi regime as an accomplished fact. France would have no choice but to acquiesce. ${ }^{94}$ That the French, following the lead of Germany and Austria, were considering making terms with Urabi, was officially revealed by Freycinet to British Ambassador at Paris, Lord Lyons, on 30 June. Lyons responded with what would be the final British position: that the "question of national honour, and of the safety of European residents in Egypt and other Mussulman countries" was now "a more immediately pressing matter than the settlement of the financial organization of Egypt”. In any case, either object required the "overthrow of Arabi Pasha and the Military party”. 95

In a speech in London, Colonial Secretary, Lord Kimberley, said that while the government believed it was “ "acting wisely in inviting the advice and concert of the European Powers"”, it was “'resolved to defend the interests and honour of the nation 'come what may’”, ${ }^{96}$ Former British Controller-General of Egyptian finances and then Suez Canal director, Sir Rivers Wilson, argued that, while Britain's interest in Egypt was primarily as the highway to India,

\footnotetext{
${ }^{93}$ The Daily Telegraph, 26 June 1882, p. 4.

${ }^{94}$ The Times, 28 June 1882, p. 7.

${ }^{95}$ Lyons to Granville, 30 June 1882, FO 407/21/1.

${ }^{96}$ Quoted in The Pall Mall Gazette, 3 July 1882, p. 11.
} 
there is more than this. We govern India by means of our prestige, some 60,000 British troops, and by the people's implicit belief in the resolution, determination, and strength of the British Empire. Without these qualities, and a confidence in them, it is not 60,000 men we should need to hold India, but an incalculably larger number; therefore, destroy that prestige and our difficulties in retaining India would enormously increase. ${ }^{97}$

These statements clearly indicate that British intervention was now felt necessary to vindicate imperial prestige on which the Empire in the East rested, by securing redress for the Alexandria massacre and Urabi's refusal to submit. The French founder and Chairman of the Suez Canal Company, Ferdinand de Lesseps, accurately claimed that the real motive of British military preparations was not to defend the Canal, which was not under any genuine threat, but to enforce the ultimatum of 25 May 1882. All that was required to secure the Canal was to come to an agreement with Urabi's Ministry, as de Lesseps had already done. ${ }^{98}$ Gladstone agreed that the Suez Canal would not come under serious threat unless Urabi was provoked by the prospect of an invasion. At the same time, however, Gladstone clearly recognised that the British government could not treat with Urabi. ${ }^{99}$

Works to the fortifications at the harbour of Alexandria had resumed in early July 1882 after being suspended with the arrival of the Anglo-French fleet in May. An ultimatum that the Egyptian military temporarily surrender the forts passed unheeded. Telegrams reached London on 11 July that British warships had opened fire on the

\footnotetext{
${ }^{97}$ Quoted in ibid., p. 10.

${ }^{98}$ The Pall Mall Gazette, 4 July 1882, p. 11; Farnie, East and West of Suez, pp. 284-285.

${ }^{99}$ See Gladstone to Granville (private), 1 and 5 July 1882, PRO 30/29/126.
} 
forts, while the French fleet had withdrawn. ${ }^{100}$ In the wake of the bombardment, Urabi's forces withdrew from Alexandria; reportedly leaving the burning city at the mercy of escaped convicts and mob violence. ${ }^{101}$ Atrocities against Christians were luridly recounted in the British press. ${ }^{102}$ The ultimatum and bombardment was not portrayed as an act of self-defence, which was the official motive, but rather as retribution for the massacres of 11 June, and a vindication of British prestige in the Orient. According to The Daily Telegraph, Britain had suffered "“Asia laughing us to scorn, while we wait upon the pleasure and leisure of Europe”". It would be "“with an outburst of angry satisfaction that Englishmen would hear at last the voice of the Queen's cannon opening on the Alexandrian murderers "’. ${ }^{103}$ The Times expressed the similar desire that the bombardment, marking one month since the Alexandria massacre, would "prove the day of retribution”. ${ }^{104}$

Both Gladstone and Dilke justified the bombardment in the House of Commons primarily on the grounds of maintaining British prestige in the East. Gladstone argued that the effect that an unavenged massacre of that kind "would have had upon the security, not only of all Englishmen and all British subjects, but of all European people throughout the whole East”, was inestimable. ${ }^{105}$ Dilke further elaborated that

\footnotetext{
100 Telegrams received, July 11, from Mr. Moore, Secretary to the Commander-in-chief, off Alexandria, 11 July 1882, FO 407/21/394.

${ }^{101}$ R. T. Harrison convincingly makes the case that the wholesale destruction of large sections of the city and up to 2,000 casualties was the result of the ten-hour, 3,000-shell British naval barrage, not of any local rioting; see Gladstone's Imperialism in Egypt, chapter 1 and photo essay.

${ }^{102}$ See, for example, The Times, 12 June 1882, p. 5; The Daily News, 12 June 1882, p. 5; The Evening News, 12 June 1882, p. 3; The Daily Telegraph, 12 June 1882, p. 5; The Standard, 12 June 1882, p. 5; The News of the World, 18 June 1882, p. 2.

${ }^{103}$ Quoted in The Pall Mall Gazette, 6 July 1882, p. 11.

104 The Times, 10 July 1882, p. 7.

${ }^{105}$ Hansard, 12 July 1882, Vol. 272, Commons, 177.
} 
it must be perfectly clear that, by massacres of this kind, European life throughout the whole of the East is endangered, and the effect of any such massacre being passed over without redress, would be to put the lives of Europeans throughout the East absolutely at the mercy of a fanatical mob of Mahomedans. We ought to remember not only the enormous number of British subjects who live in Egypt and abroad, but the immense interests which our country possesses, and which were protected during late years by the sanctity of European life observed throughout the East. ${ }^{106}$

The documentary evidence suggests that Gladstone acquiesced to a British military intervention sometime between the bombardment of 11 July and 20 July 1882. In a despatch ostensibly to Dufferin dated 11 July, but released publicly on 20 July as a Parliamentary Paper, Granville stated the official government position that only force could now put an end to the intolerable state of affairs in Egypt. The restoration of prestige in Egypt was prerequisite for the protection of British interests throughout the world. $^{107}$

Orders were issued on 20 July 1882 to increase British forces in readiness at Malta and Cyprus. The cost of a military expedition was to be placed before Parliament as a Vote of Credit on Monday 24 July. Paris advised on 22 July that pending parliamentary approval, it would participate in measures to secure the Suez Canal only, but not extending to the interior of the country. ${ }^{108}$ The Italian government

\footnotetext{
${ }^{106}$ Ibid., 190-191.

${ }^{107}$ See 'Copy of a Despatch from Earl Granville to the Earl of Dufferin respecting the Affairs of Egypt', 11 July 1882, Parliamentary Papers, Egypt. 10 (1882).

${ }^{108}$ Lyons to Granville, 22 July 1882, FO 407/21/804.
} 
also confirmed on the same day that it would be willing to participate with Britain but not in any arrangement that included France. ${ }^{109}$

As these contradictions among the Powers at the Conference played themselves out to a standstill, the drumbeat in the British press demanding action reached a crescendo that no elected government could fail to heed. The tempo and urgency of the press coverage after the bombardment served to reinforce Cabinet decision-making toward unilateral intervention. In fixating on the "atrocities" and "massacres" inflicted on Europeans and other Christians in Alexandria, ${ }^{110}$ foreign affairs' reporting fully engaged the public's concern for imperial order. For example, The Daily Telegraph sensationally recounted that "the Arabs" had killed "all the Christians they could find". ${ }^{111}$ The scene at Alexandria was a "ghastly catastrophe", with the ancient city in ruins, "pillaged by Egyptian soldiers and Arab mobs". ${ }^{112}$ The press coverage reached a crescendo in the days leading up to and during the four-night parliamentary debate that gained fiscal approval for the military expedition. On 21 July 1882, the Evening News reported that more Europeans had been murdered, with "further massacres imminent". ${ }^{113}$ Both the News of the World and The Daily News carried stories on the following days that the mass murder of Christians was spreading from Alexandria to Cairo, Port Said and elsewhere. ${ }^{114}$

\section{The case for British intervention}

The case for a unilateral British intervention was made before both Houses of Parliament starting on 24 July 1882. In the Lords, Granville confirmed that there was

\footnotetext{
${ }^{109}$ Granville to Paget, 22 July 1882, FO 407/21/817.

${ }^{110}$ See The Pall Mall Gazette, 13 July 1882, p. 8; The Evening News, 13 July 1882, p. 3; The Morning Post, 14 July 1882, p. 5.

${ }^{111}$ The Daily Telegraph, 14 July 1882, p. 5.

${ }^{112}$ See The Daily News, 14 July 1882, p. 5; The Evening News, 14 July 1882, p. 3; The News of the World, 16 July 1882, p. 2.

113 The Evening News, 21 July 1882, p. 3.

${ }^{114}$ The News of the World, 23 July 1882, p. 2; The Daily News, 24 July 1882, p. 5.
} 
no remedy to the situation without the application of force. The Powers would not give formal mandates, but Granville was convinced of "their good will, their good wishes" and "their moral support”. Granville also made the crucial point of prudence. This confidence would not "have been felt either by France or by the other powers if, three or four months ago, by a precipitate course, we had taken sole action upon ourselves. At this moment, however, Europe is entirely prepared for such a contingency". 115

Later in the House of Commons, Gladstone and other Ministers defended their policy largely on realist grounds. The government had "no desire to impart a shock to the fabric of the Ottoman Empire”, and had firstly sought the intervention of Turkey as legitimate Suzerain. The Cabinet’s next desire had been to make prudent “appeal to the common authority of Europe, and to avoid, above all things, the exhibition of a disposition of a line of isolated action”. Gladstone argued that the government had "laboured hard to bring together the Conference", but had failed to gain a mandate, although it claimed to enjoy "the moral support and concurrence of Europe". France would go no further than the Canal. But, in clearly indicating the derivative nature of the Suez Canal, Gladstone then asserted that "the insecurity of the Canal is a symptom only, and the seat of the disease is in the interior of Egypt, in its disturbed and its anarchical condition”. ${ }^{116}$ This shows that in Gladstone’s understanding, it was the restoration of imperial order that was the primary object of the intervention.

Both Dilke and Joseph Chamberlain developed this theme further and explicitly asserted that the motive for restoring order in Egypt was the maintenance of British prestige in the East. Dilke argued, "it is impossible to permanently acquiesce in any arrangement in Egypt, especially after the massacre at Alexandria on the 11th

\footnotetext{
${ }^{115}$ Hansard, 24 July 1882, Vol. 272, Lords, 1493-1494.

${ }^{116}$ Ibid., Commons, 1582-1586.
} 
of June, which would destroy, not only the influence and credit of this country, but of all Europe in the East. ${ }^{117}$ Chamberlain said that he could not "conceive anything more dangerous to the security of our people and to the security of our Possessions that an idea should get abroad that we could be set at defiance with impunity”. ${ }^{118}$

Both Childers and Gladstone elaborated the crucial prudential argument on the final night of the debate. Childers pointed out, "if we had adopted a different course we should have had serious difficulties with France ... In all probability we should have run the risk of a serious war ...”119 In his final remarks, the Prime Minister made clear that a realist ethic of prudence had guided Cabinet decision-making throughout the Egyptian crisis. Gladstone concluded that "our greatest and most imperative duty in approaching this question of Egypt ... [was] that under no consideration could that local difficulty be allowed to grow into a ... European war”. The result of an early break with France would have "been a sharp conflict in Egypt, where the two countries would have been divided into separate camps, and, as I believe, a general European war”. 120

On 29 July 1882, the French government was defeated on a Bill of Credit for its participation in the protection of the Suez Canal and took no further part. ${ }^{121}$ Advice from British Ambassadors on the Continent was that Germany and Austria would not oppose an intervention, but neither would they sanction it. ${ }^{122}$ The way to a unilateral British intervention was finally cleared on 2 August when Russia declined any active opposition. $^{123}$ Anglo-Indian forces secured the Suez Canal on 20 August. Urabi's

\footnotetext{
${ }^{117}$ Hansard, 25 July 1882, Vol. 272, Commons, 1721.

118 Ibid., 1801.

${ }^{119}$ Hansard, 27 July 1882, Vol. 272, Commons, 2010.

${ }^{120}$ Ibid., 2097-2100.

${ }^{121}$ Lyons to Granville, 29 July 1882, FO 407/21/1075.

${ }^{122}$ For example, Granville to Sir J. Walsham (Berlin), 18 July 1882, FO 407/21/654; Dufferin to Granville, 20 July 1882, FO 407/21/746.

${ }^{123}$ Sir E. Thornton (St. Petersburg) to Granville, 2 August 1882, FO 407/22/180.
} 
army was defeated at Tel-el-Kebir on 13 September. Cairo was occupied and Urabi captured two days later.

\section{Conclusion}

This reinterpretation of the motives for the 1882 British occupation of Egypt suggests that, for a status quo imperial Power, the maintenance of prestige is the fundamental interest from which security and wealth flow. That a moralistic Liberal government elected on a non-interventionist platform undertook the Egypt occupation strongly implies that this imperative overrides partisan domestic politics. The overturning of the Anglo-French Control by Urabi’s National Party in early February 1882 dealt a severe blow to British prestige, which raised serious concerns about imperial order on the subcontinent in the wake of the Indian Mutiny, and in the East more generally. Considerations of prudence, however, dictated that any action in Egypt had to be weighed against the disposition of the Powers. The Cabinet deemed some form of armed intervention absolutely necessary only when the situation at Cairo assumed an outright revolutionary character in May 1882.

Between 11 May 1882 and the despatch of Anglo-Indian forces in early August, the Cabinet had to formulate a mode of intervention to vindicate British prestige while also averting Great Power conflict. The sensitivity of public opinion to the deteriorating events in Alexandria and Cairo and their consequences for British prestige abroad, as evinced in the clamour of the press, definitively precluded Cabinet inaction. A realist ethic of prudence, on the other hand, served to dampen the possibility of any precipitous military action. From late-May 1882 until the Conference of the Powers was seen to have run its course by 22 July, British pressure for Turkish intervention and then a European-mandated action became increasingly disingenuous. The Conference, which the evidence suggests was always viewed as 
unlikely to arrive at any clear outcome, served the prudential function of being seen to consult, while in the background military preparations were carried on. The government's case for intervention was made to the Parliament on realist grounds: that a policy of unilateral British intervention to restore imperial prestige could now be pursued was only possible due to the observance of an ethics of prudence in its formulation. 